\title{
THE HAGUE CONVENTION ON THE LAW APPLICABLE TO TRAFFIC ACCIDENTS AND ROME II REGULATION**
}

\begin{abstract}
The Hague Convention on the Law Applicable to Traffic Accidents (hereinafter: the Convention) contains harmonised rules regarding the law applicable to non-contractual liability for damage arising from traffic accidents. According to the Convention, a traffic accident is an accident which involves one or more vehicles, and is connected with traffic on a public highway, in grounds open to the public or in private grounds to which certain persons have a right of access. The rule is adapted to the specifics of road transport, objectified according to certain facts in the particular case. The Convention introduces something new into the existing system of conflict of laws resolution based on relevant facts i.e. the application of the law of the place of vehicle registration when there is only one vehicle involved, in the accident which is registered in the country which is not the place of the accident, or when there are more vehicles involved in the accident which are registered in the same country which is not the country of the accident. The basic aim of the Convention was to facilitate the compensation of damage by means of automobile liability insurance and improvement of the position of the injured parties. In relation to determining the law applicable to non-contractual liabilities, the EU enacted the Regulation Rome II which does not provide solutions for road traffic accidents but general standards of the Regulation (article 4) are applied in such cases.
\end{abstract}

Key words: damage, traffic accidents, applicable law, EU law.

\footnotetext{
*marija.krvavac@pr.ac.rs

** This paper was presented at the International Scientific Conference "Law in the context of addressing the Challenges of the Contemporary World", held at the Faculty of Law, University of Niš, on $13^{\text {th }}-14^{\text {th }}$ April 2018.
} 


\section{Introduction}

In the proceedings of making a resolution on its own merits, the problem of non-contractual liability for damage caused, legally and factually involving two or more countries, creates a problem for competent authorities and opens the problem of conflict of law resolution. The changes of rules on civil liability at a national level affect the change of attitude regarding different kinds of liability and the manner of indemnification. Particularly complex issues concern noncontractual liability for damage caused by a traffic accident in situations with an international element. The adoption of several international conventions which contain substantive and conflict of law solutions has not eliminated the problem of smaller or larger differences in regulating non-contractual relations. Namely, courts usually apply the domestic law provisions, except when it comes to the provisions of private international law i.e. conflict of law rules, which may involve the application of the rules of a foreign legal system. It particularly refers to the application of convention conflict of law rules.

The efforts of the Hague Convention regarding private international law to harmonise the conflict of law issue resulted, inter alia, in enacting the Convention on the Law Applicable to Traffic Accidents (hereinafter: the Hague Convention). At the same time, the efforts of theory and practice of Acquis Communautaire towards more righteous and efficient compensation for damage arising in many cases actualised the harmonisation of non-contractual liability at the regional level, which enabled the enacting of Regulation (EC) no. 864/2007 on applicable law for non-contractual obligations (Rome II Regulation) ${ }^{1}$

Today the Regulation is universally applied within the EU, in relation to interior disputes as well as in relation to disputes with an international element. Thus, the European legislation abandons the double track of private international law, which includes different legal provisions on private legal disputes involvingMember States subject matterin relation to the non-member States, regarding the harmful event arising after its entry into force.

\section{The Hague Convention on the Law Applicable to Traffic Accidents}

The unification of the conflict of law rules at the universal level within the Hague Convention for private international law includes the Hague Convention on the Law Applicable to Traffic Accidents of $4^{\text {th }}$ May 1971. The document entered into force in 1971 and it has been applied in the Republic of Serbia since 1976. ${ }^{2}$

1 Rome II Regulation, OJ EU 199/40 as of 31st July 2007.

2 "Official Gazette of the Socialist Federal Republic of Yugoslavia"- International Treaties no. 26/76. The contracting parties are Belgium, Bosnia and Herzegovina, France, Croatia, 
The Convention contains the harmonised rules regarding law applicable to civil non-contractual liability for damage arising from a traffic accident, whichis defined as any accident involving one or more vehicles and connected with traffic on the public highway, in grounds open to the public or in grounds to which certain persons have a right of access. Accordingly, the Convention accepts the rule on application of the law on non-contractual liability for damage arising out of traffic accidents in connection with the place of accident, i.e. it assumes a regular conflict of law rule which provides for application of the substantive law of the State where the accident occurred. ${ }^{3}$ The rule is adjusted to the specifics of road traffic made objective according to certain facts in a particular case. The objectives of this harmonisation are: to remove the uncertainty of the general phrase ("close connection with the place of accident" which could lead to different solutions for a longer period of time), until the court practice of the signatory countries is harmonised, considering the fact that a judge decideson the merits of each case; to optimally adjust the conflict of law to the specifics of the road traffic, and to exclude the possibility of resolving the conflict of laws which would be the result of accidental circumstances.

Lex loci delicti commissi remains the basic conflict of law convention rule. It implies the applicability of the internal law of the State in which the damage was caused by a traffic accident, which excludes the use of renvoi (sending back and redirecting to another law). At the same time, the Convention introduces a new fact into the existing system of conflict of laws, i.e. the application of the law of the place of registration of the vehiclebased onrelevant facts, when only one motor vehicle took part in the accident but it is registered in the State which is not the State of the accident; or when several vehicles registered in the same State, which is not the State of the accident, took part in the accident. ${ }^{4}$ In case of

Lithuania, Latvia, Luxembourg, Macedonia, Morocco, Montenegro, the Netherlands, Ukraine, Austria, Poland, Serbia, Slovenia, Slovakia, Czech Republic, Belarus, and Switzerland. Retrivied 21 July 2018 from www.hhcch.com

3 Article 3 of the Convention.

4 Article 4 (a) (b) of the Convention. From foreign court practice: The judgement of the Court of Appeals in Paris, June 1981, in the dispute Brandicort v Bigu regarding a traffic accident in Morocco. In order to avoid the collision with a car registered in Morocco, Bendicot, driving a car registered in France with 5 passengers in it, turned off the road and went down the embankment. One person died in the accident and the others were injured, one of whom brought an action against the vehicle owner for compensation of damage. The first instance court applied Article 4 of the Hague Convention and ruled that the applicable law is French law, i.e. the law of the place of the registration of the vehicle. The court decided that only one vehicle with one licence plate took part in the accident. The determination of the applicable law was even more difficult considering the fact that there was no direct contact of the vehicles, but the driver of the French car avoided the collision and thus caused the accident. However, the Court of Appeals decided that the Moroccan vehicle caused the accident and that two 
several people being involved in the accident, the applicable law is determined for each one of them individually. The vehicles which are registered in several countries, or are not registered at all, are subject to the law of the State of "habitual residence" which is applied instead of the law of the State of the place of registration of a motor vehicle in the function of a conflict of law solution. Applicable law includes the issues of conditions and scope of liability, reasons for release from liability, nature and kind of damage, the circle of persons who have the right to compensation of damage, burden of proof, liability of the principal for the actions of a person under their control, statute of limitations, etc. Besides, the applicable law regulates the right of the aggrieved party to initiate a proceeding against the insurer, as well as any other issues which a judge finds appropriate to apply.

The Convention does not oblige the signatory countries to introduce direct action against the insurer, but directly refers to the applicable law according to the conflict of law rules and states that the damaged parties have the right to a direct action if such action is recognised according to the law applicable for compensation of damage. The exceptions to this rule are set in favour of the aggrieved party if the applicable law does not recognise a direct action, but this right is recognised according to lex loci delicti, or if the right to a direct action is not recognised according to any of these two rights but it is possible according to the law of the place where the insurance contract was entered into.

The application of the law where the traffic accident occurred may be unfavourable for the aggrieved party if it provides for less indemnification that the indemnification which may be achieved according to the law of their own State. When there is a bigger difference among the regulations on liability, it usually refers to the amount of compensation for damage according to the rules of the State of the accident; for this reason, EU law stipulates that the law which is more favourable to the aggrieved party may be applied for liability for damages arising from traffic accidents. Namely, the court needs to determine, either ex officio or at the request of the aggrieved party, by comparing the decisions based on the law of the place of the tort with the law of place of damage, which of these laws is more favourable for the aggrieved party. Inability to determine the content of the applicable foreign law gives rise to the application of lex for $i$ or the application of the law which is closest to the unknown, i.e. probably the application of applicable law.

vehicles of different places of registration took part in the accident; hence, Moroccan law needed to be applied, i.e. lex loci delicti commissi. Revue Critique, no 416, janvier 1982 p. 691. 


\subsection{More precise determination of Convention solutions}

The purpose of regulating private and legal relationships with a foreign element is reflected in a uniform or approximately equal resolution of a dispute, regardless of the fact which State authority deals with it. The courts have to take into consideration the principle of the choice of law which is most closely connected to the dispute and the law the application of which was justifiably expected by the parties, as well as the balance of the solutions (Collins, 1993:5). At the universal level, the prevailing attitude is that the provisions of the convention need to be considered as autonomous international collection of legal standards which is, according to its meaning, independent from the national law of countries (Gebauer, 2000:685). According to the Vienna Convention on the Law of Treaties, the convention has to be interpreted in good faith, according to the regular meaning of expressions from agreements and taking into account the subject and purpose of the agreements. ${ }^{5}$ The courts of the signatory countries are obligated to apply the Hague Convention rather than domestic conflict of laws rules when deciding on non-contractual liability for damage caused by a road traffic accident. However, in the Serbian court practice, domestic Act on Resolving Conflict of Laws with Regulations of Other Countries is applied more frequently, considering the fact that the area of application of Article 4(a), indent 2 , regarding the phrase "liability to the victim who was a passenger" is undefined; in that regard, we may ask a question if it is a direct victim of the accident or the family of the passenger that also belong here. ${ }^{6}$ The conflict of

5 "Official Gazette of the Socialist Federal Republic of Yugoslavia"- International Treates, no. 30/1972, a provision of article 31, paragraph 1 of the Convention.

6 From foreign court practice: The judgement of the Supreme Court of the Republic of Croatia, 878/08-2-18. 03 2010, case Nikolić and others vs. insurance agency. A citizen of the Republic of Serbia died in a car with Slovenian licence plates in which car there was another passenger. The family, Serbian citizens, initiated a proceeding for damages against the Croatian insurance agency. By applying the Hague Convention, the first instance court applied Croatian law and the law of the place of the accident, in spite of the fact that the Hague Convention provides for deviation from the application of the law of the State of accident in favour of the law of the place of registration of the vehicle, in this particular case the law of Slovenia. The decision of the first instance court way confirmed by the second instance court (the judgement of the Vukovar County Court, gž-249/07 as of $23^{\text {rd }}$ January 2008). However, the defendant asked for a review and contested the application of Croatian law stating, inter alia, that the court should have applied the law of the place of registration of the vehicle, i.e. the law of Slovenia. The Supreme Court rejected the objections of the defendant considering that the provision of article 4 of the Convention represents an exception from the principle from article 3 and it refers only to the persons which are expressly Stated in that provision: drivers, the owners of the vehicle, the victim who was a passenger or the victim who was in the place of the accident outside the vehicle. In this particular case the plaintiffs are none of these persons so the provision form article 3 of the Convention is applied to them. Therefore, the Supreme Court considered exclusively the text of the Convention when interpreting the application of the 
law solution of the Hague Convention provides, depending on particular situation, the application of the law of the State where the accident happened or the law of the State where a vehicle is registered. ${ }^{7}$ At the time of the enactment of the Convention, comparative law and court practice widely applied the law of the State where the accident occurred (Dutoit, 1968:20), considering the fact that the accident represents the issue of non-contractual liability for damage; thus, as the law of the State of the accident is most coincidental, we cannot talk about the application of law in the closest connection with the dispute. Although presented as an exception to lex loci delicti, the law of the registration of the vehicle is more frequently applied in practice than a general rule. If the vehicle is registered outside the State in which the accident occurred, the application of the law of the State of registration is conditioned by the fact that the common residence of directly aggrieved party is also outside the State in which the accident occurred. The application of the law of the place of registration of a vehicle represents derogation from the application of lex loci delicti commissi in favour of the application of the law which has closer and more important connection with the dispute (Kadner Graziano, 2004:38)

The Hague Convention does not contain the rule on deciding upon applicable law by the participants in the accident by mutual consent. ${ }^{8}$

In relation to the field of application of the applicable law, the Convention expressly provides that the permission for the family to claim damages must be judged according to the applicable law for non-contractual liability for damage. ${ }^{9}$ This conflict of law solution must be loosely interpreted, i.e. it needs to be applied in adjudicating on the wrongdoer'sliability for damage sustained by the direct victim, a passenger, indirectly aggrieved party, the family of the passenger (Tomljenović, 200:132). In the application of the Convention, the court practice of the signatory countries starts from literal or wider interpretation of the scope of conflict of law provision (Sumampow, 1996:263). For example, the courts of France and Austria accept the method of wider interpretation of Article 4 (a),

provision of article 4. Remark by Vesna Tomljenović, The interpretation of conflict of lawrules of international conventions - an example of the interpretation of conflict of laws provision of the HagueConvention on Traffic Accidents, Collection of PFZ, 62, (1-2) 2012, p.101-152.

7 Articles 3-6 of the Convention.

8 In the dispute Roho c. Coron et. al. in relation to damages for a traffic accident in Djibouti the Court of Cassation of France applied the implied agreement of the parties that French law is applicable law considering the fact that the parties have the possibility to select the applicable law different from the law defined by the Convention conflict of law rules. The decision of the Court of Cassation of France in the case Roho c. Caronet. al. Cour de Cassacio $19^{\text {th }}$ April 1988 RCDIP (Revue Critique de droit international privé) 1989, p. 71.

9 Article 8, point 6 of the Convention. 
indent 2.The cases when the Hague Convention is not applied are listed as follows: the liability of the manufacturer, seller and servicer of the vehicle; the liability of the road owner or any other entity that is responsible for road maintenance or security of the users; the liability for the actions of another entity except for the liability of the owner of the vehicle or the ordering party; recourse demands between the responsible parties; recourse claims and subrogation referring to the insurer; claims and recourse claims by social security institutions or other similar institutions and public grant funds for damage caused by a vehicle or against which these claims are filed, as well as the cases of exclusion from liability provided by the law these institutions are part of. ${ }^{10} \mathrm{The}$ Convention accepts the possibility of correction in regular application of conflict of law solutions if it points to the application of foreign law which is obviously in contravention with the domestic public policy (Varadi, Bordaš, Knežević, Pavić, 2011: 146). Special problems in applying conflict of law solutions arise in cases when it points to the law of the state with a complex system and, even if the choice has been made, there is a question how to determine applicable law within such state (Živković, Stanivuković, 2004:311). The state which does not have a unified legal system is not bound to apply the Convention for the accidents which occur in its territory involving only the participation of vehicles registered in the territorial units of that state. According to the Convention, each territorial unit which makes part of the state which does not have a unified legal system is considered a state for the purpose of application of Articles 2-11 if it has its own system in the area of civil non-contractual liability arising from traffic accidents. ${ }^{11}$

\section{Regulation (EC) No. 864/2007 on the law applicable to non-contractual obligations (Rome II)}

The national provisions of conflict of laws for non-contractual liability for damage influenced the development of European international tort law by the introduction of new relevant facts in the conflict of law solutions which need to contribute to the principle of the closest connection and flexibility of solutions.

The Rome II Regulation was enacted within the framework of general objectives of the EU to develop freedom, safety and legal area in which the free movement of people is allowed (Article 2, indent 4, of the Treaty on European Union). By the Regulation on the law applicable to non-contractual obligations (hereinafter: the Rome II Regulation), ${ }^{12}$ the EU legislator has been trying to unify conflict of

10 Article 2 of the Convention.

11 See Article 12-14 of the Convention.

12 Official Journal of the European Union L 199, 31 $1^{\text {st }}$ July 2007. Trying to harmonise the European law concerning non-contractual liability for damage, the EU enacted the Council 
law rules for non-contractual liability for damage within the EU, as well as to make it easier to apply the principles of mutual recognition of judgements in civil and business cases. Apart from the general conflict of law rules, the Regulation contains several separate solutions concerning certain forms of non-contractual liability for damage. Considering the fact that some of the EU members are at the same time the contracting states of the Hague Convention on traffic accidents, the Rome II Regulation gives an advantage to the solutions from the Hague Convention in application (Kunda, 2007;1269-1324). We can conclude that the courts of the member states apply conflict of law standards of the treaties in force but the courts of the member states which are not parties to such agreements apply the provisions of the Rome II Regulation. ${ }^{13}$ Considering its legal force, the Regulation is above the Hague Convention and international treaties entered into only between two or more member states, if such international treaties regulate the relationships contained in the Regulation. ${ }^{14} \mathrm{~A}$ contracting state of this Convention may at the same time be a member to another convention which contains provisions on non-contractual liability for damage in special area, in which case the Hague Convention does not have influence on their effect. ${ }^{15}$ In the member states which have not ratified the Hague Convention on law applicable to traffic accidents, the applicable law concerningthe liability for damage caused by a traffic accident is determined according to the general conflict of law rule, considering the fact that the Rome II Regulation does not have a separate conflict of law solution for this kind of liability.

The enactment of the Rome II Regulation has not achieved full unification;thus, in the member states, the Convention still prevails over the Rome II Regulation. This refers to international liability of the parties, i.e. the member states, in

Directive 72/166/EEC as of $24^{\text {th }}$ April 1972 regarding the harmonisation of the laws of the member states in relation to insurance from civil and legal liability regarding the use of motor vehicles and the obligation of insurance from such liability (Official Journal 1972, L 103 p. 1). From the practice of European Court: Upon a request for preliminary decision pursuant to Article 267 UFEU which was sent by the Tribunal/Court of Appeals in Guimaraes, Portugal, by the decision of $23^{\text {rd }}$ June 2016 in the caseIsabel Maria Pinheiro Vieira, Rodriges de Andrande, Fausto de Silva Rodriges de Andrade v. Josea Manuela Proenqe Salvadora; Crédito Agricola Seguros; Companhiade Seguros e Ramos Reaissa; Jorgea Oliviere Pinta, the Portuguese court applied for the interpretation of Article 3, para.1 of the Directive no.72/166. Within the dispute between the spouses Andrade and CA Seguros as one party and J. O. Pinta as the other party, the Court ordered the spouses to pay damages to J. M. P. Salvador because of the death of his wife in the accident (involving a tractor) which occurred on the farm where she was working.

13 The states which are not signatories to the Hague Convention are: Bulgaria, Estonia, Finland, Ireland, Italy, Hungary, Germany, Portugal, Romania, Sweden and Great Britain.

14 Article 28, paragraph 2 of the Regulation

15 Article 15 of the Hague Convention. 
relation to the ratified convention by acceptance of obligation. The non-member states to the Convention apply the Regulation, except for Denmark where internal conflict of law rules on non-contractual liability for damage are applied. Pursuant to Article 29, paragraph 1, some member states have submitted to the Commission a list of cancellation of the conventions which contain conflict of law rules for non-contractual liability to which they were bound. The Commission has published the list in the Official Journal of the EU. ${ }^{16}$

The provision does not contain a special solution for road traffic accidents but general standards envisaged in Article 4 are applied, as well as Article 14 which provides for the choice of applicable law by the parties. Notably, a provision in the preamble of the Convention is clearly aimed at protecting the injured party: "according to the international rules regarding the damages to the victims of a traffic accident in cases where the accident occurred in the state other than the state where the victim has habitual residence, the court before which the proceeding is initiated needs to consider all the relevant circumstances which refer to such victim, including real loss and expenses of subsequent care and medical help,when calculating the damages (point 33)" (Babić, 2009:17).

Under the general conflict of law rule, the liability for the damage caused by a traffic accident is subject to the law of the state where the accident occurred -lex loci damnum ${ }^{17}$, whereby it is not significant in which state the harmful event which caused the damage occurred and where the consequence resulted. In the Proposal for a Regulation, the Commission explains that the place of indirect damage is not significant for determining the applicable law. In relation to this, there is a question of applicable law for the claims submitted by an indirectly damaged party; in such a case, the doctrine refers to the law which is applicable

16 Official Journal of the EU, C-343/05 as of $17^{\text {th }}$ December 2010.

17 Article 4 of the Regulation. In the unified case C-359/14 and C-475/14 in the dispute Insurance $S E$ v I F P\&CInsuarance AS and Gjensidige Baltic AAS v PZU Lietura UAB DK, the Court held that the regulations Rome I (Regulation on the Law Applicable to Contractual Obligations) and Rome II need to be interpreted so that the law which needs to be applied to recourse action of the insurer of the tow vehicle which compensated the damages to the victims of the accident, which was caused by the driver of the said vehicle in relation to the insurer of the insurer of the trailer is determined pursuant to article 7 of Rome I Regulation. Pursuant to article 4, the law applicable to such non-contractual liability is the law of the state in which the damage occurred, in which the damage was suffered directly from the accident. Pursuant to Article 15 item (a) and (b) of the same Regulation, such law regulates the conditions and the scope of liability as well as the reasons for the division of liability. Retrieved11.07.2018 from:

curia.europa.eu/juris/document/document.jsf?text=applicable\%Blaw\%2Bto\%Btraffic\% 2Baccident\&docid. 
to the primarily damaged party. ${ }^{18}$ Similarly to Article 8 of the Hague Convention, it is expressly determined that, according to the applicable law on the liability to a directly injured party, the circle of parties who have the right to claim damages as indirect consequence of the damage suffered by the directly damaged party has to be determined. In the context of acquis communautaire private international law and the application of Rome II Regulation, there is a prevailing attitude that there is no reason for the choice of applicable law to be different in cases involving indirect lyor directly damaged parties.

\subsection{Freedom of choice}

The regulation allows the party to choose applicable law, which was characteristic of contractual relationships with a foreign element for a long time. Pursuant to Article 14, the parties may, by mutual consent, select the law under which the issues of non-contractual liability for damage will be resolved (Dickinson 2009:13.01), by a special agreement after the event which caused damage or before the harmful event if all the parties do business activities. The choice of applicable law may be express or tacit, which arises from the circumstances of the case with reasonable certainty. Rome II Regulation provides standard measures of protection of the party autonomy by introducing compulsory regulations. ${ }^{19}$ The conditions set in relation to the choice of applicable law by the parties

18 In the case C-350/14 of the European Court in relation to the dispute Florin Lazar v. Allianz SpA, the request for preliminary decision was filed by Tribunale de Trieste regarding the terms "the state in which the damage occurred", "damage" and "indirect consequences of an unlawful action" in the dispute of the family members of the person who died after a traffic accident. The goal of Rome II Regulation is harmonisation of the conflict of law rules in cases of non-contractual liability for the purpose of legal safety and taking into account legitimate legal interest in question. The Regulation does not aim to harmonise substantive EU law in that area. Thus, when a judge applies the terms which are differently accepted in different countries and the scope of which may vary in different legal systems, he/she may find himself/herself before a problematic task. This is particularly true if the applications of the persons who do not have habitual residence in the same country have been submitted within the same dispute. Article 4 of the Regulation in such case needs to be interpreted in a way that regarding the damage suffered by family of the deceased victim of the accident in the state they have residence they may initiate a proceeding in a member state and be included in the concept "indirect consequences". The concept "the state in which the damage occurred" must be interpreted within the meaning of the place in which the traffic accident had harmful consequences. Retrieved11.07.2018 from: curia.europa.eu/juris/document/ document.jsf?text=applicable\%Blaw\%2Bto\%Btraffic\%2Baccident\&docid.

19 Restrictions of article 14, paragraph 2 are the same as with Rome I Regulation so that "Where all the elements relevant to the situation at the time when the event giving rise to the damage occurs are located in a country other than the country whose law has been chosen, the choice of the parties shall not prejudice the application of provisions of the law of that other country which cannot be derogated from by agreement". "If all the other elements 
are formulated in such manner that they primarily strengthen the position of the weaker party. The possibility of expressing the parties' choice of the applicable law is expressly excluded by Article 6 which refers to unfair competition and acts which restrict free market competition as well as in relation to Article 8 which refers to the violation of intellectual property.

Freedom of choice is restricted in the following situations: a) when the circumstances of the case at the time when the damage occurred are located in the state other than the state whose law the parties choose as applicable (Article 14, paragraph 2); b) by their choice the parties may not derogate from acquis communautaire when all the circumstances of the case, at the time when the damage occurred, are located in the territory of one or more states in which the Regulation is in force (Article 14, paragraph 3); c) by the rules of direct application pursuant to Article 16 of the Regulation, although in Article 14 there is no provision of direct reference to this article.

The subjective point of reference, the freedom of choice, represents an option prescribed by the Regulation of general conflict of law rule for non-contractual liability for damage. It receives the rank of primary point of reference which, together with the rest, needs to create "a corresponding measure" of flexibility in the conflict of law rule.

\section{The reform of the Serbian conflict of law for non-contractual liability for damage}

By enacting the Act on Resolving Conflict of Law with the regulations of other countries, ${ }^{20}$ the former SFRY embarked on the codification of private international law, including the codification of general conflict of law solutions for tort obligations (Dika, Knežević and Stojanović, 1991:6). For some cases, the Act provides (unless provided otherwise) that the applicable law for non-contractual liability for damage is the law of the place where the action was performed or the law of the place where the consequence occurred, depending on the fact which of these is more favourable to the damaged party. A single conflict of law solution includes all the cases of non-contractual liability for damage for which there is no special national or international conflict of law solution, which is the

relevant to the situation at the time when the event giving rise to the damage occurs are located in one or more of the Member States, the parties' choice of the law applicable other than that of a Member State shall not prejudice the application of provisions of Community law, where appropriate as implemented in the Member State of the forum, which cannot be derogated from by agreement".

20 The Law on Resolving Conflict of Law with the regulations of other countries, "Official Gazette of the Socialist Federal Republic of Yugoslavia" no 43/82, 72/82 and "Official Gazette of the Federal Republic of Yugoslavia" no 49/96 and "Official Gazette of the Republic of Serbia" no 46/06. 
case with the conflict of law solutions of the Hague Convention on applicable law for traffic accidents. The Convention is applied in Serbia as a member state on the basis of notification on succession. Due to the international origin of the Convention, in the domestic doctrine there is a prevailing attitude that the method of autonomous interpretation needs to be applied to the provisions of the Convention, which was confirmed by the European Court of Justice.

The opinion of the Supreme Court of Serbia is that the Convention has to be applied to civil liability arising from a traffic accident, regardless of the kind of tribunal competent to resolve it. In such case, civil liability is subject to domestic legislation of the state in whose territory the damage occurred.

Serbia is awaiting the enactment of a new codification of private international law, considering that the final Draft Code on Private International Law (hereinafter: the Draft PIL Code), ${ }^{21}$ which contains conflict of law solutions harmonised with the law of the European Union, has already been made.

Thus, Article 165 of the Draft PIL Code stipulates that the parties may choose applicable law for non-contractual obligations after the harmful event or before the harmful event, provided that the parties do business activity. The choice must be manifestly made or undoubtedly arise from the circumstances of the event. If, at the moment of the occurrence of the harmful event, all the decisive circumstances are related to the state the law of which was not selected, such choice does not affect the application of the provisions of the law of the other state, from which it is not possible to derogate. The Draft PIL Code provides that the applicable law for non-contractual liability for damage is the law of the state in which the damage occurred, regardless of the fact in which state the harmful event occurred or in which state the indirect consequences of that event occurred, which is a different conflict of law solution in relation to the applicable Acton Resolving Conflict of Law which is still in force. If the responsible party and the damaged party have residence in the same state at the moment of the occurrence of damage, the law of that state is applicable for non-contractual liability. The new provision provides that, if it is clear from all the circumstances that the harmful event is obviously in significantly closer connection with another state, the law of that other state is applied.

Unlike the Rome II Regulation, the Serbian Draft PIL Code on Private International Law standardises the matter of road traffic accidents in Article 172,but it refers to the application of the Hague Convention in order to determine noncontractual liability arising from damage in a road traffic accident. Thus, as a

21 TheDraft Code on Private International Law of the Republic of Serbia; Retrieved 16 July 2018 from www.mpravde.rs 
contracting state, it complies with the international legal system and the obligations accepted at the international level.

The domestic court practice applies the Hague Convention, i.e. the conflict of law rule from Article 3, which refers to the implementation of internal (substantive) law of the state in which the accident occurred, which is best known by domestic judges. In Serbian court practice, there are not so many decisions of this kind, and one of them was rendered in a case of an action taken by a Serbian citizen who suffered serious body injuries in a car accident which occurred in Iraq. The accident was caused by a truck with Bulgarian licence plates and a truck with Serbian licence plates registered with "Dunav" Company. The injured person was in the vehicle driven by the Serbian driver. In order to effectuate his right to damages, Lj. Stevanović sued the Association of Insurers of Yugoslavia (at the time), the "Dunav" Company and the Bulgarian insurance company "Bulstrad" from Sofia. It was the case of shared liability.

Among other things, it was disputable which law was applicable in this case: the law of Iraq lex loci delicti or the law of the former SFRY. According to the Hague Convention, it would be the law of Iraq as lex loci delicti commissi. However, when the territory where the harmful event happened does not match the state of the consequence, the localisation of the event is done by the application of the so-called theory of the state where the law which is more favourable to the damaged party is applied. The domestic law would be also applicable according to the principle of private international law which takes the domicile, citizenship and habitual residence as the point of reference, and the damages are provided in the proceeding which depends on the point of reference. In this case, the law of Serbia was applied as the consequences occurred in the SFRY, more precisely in today's Serbia. ${ }^{22}$

\section{Conclusion}

The solutions of the Hague Convention on the law applicable to road traffic accidents are deeply rooted in the national systems of private international law. In the procedure of harmonising different attitudes, there wererather complex solutions, whose application required the attention and competence of competent authorities.Years later, the endeavours of the EU regarding the standardisation of law in general and the conflict of law rules in particular have had a strong influence on all national systems of private international law. Cross-border events resulting in damage raise a series of issues which equally concern all the

22 From the domestic court practice, see: Decision of the Supreme Court Rev-105/06 as of $10^{\text {th }}$ May 2006; Rev-3031/05 as of $13^{\text {th }}$ April 2006; Rev/06 as of $1^{\text {st }}$ February 2006. Retrieved 14.07.2018 from: www.rs/sr-lat/baza-sudske-prakse-suda 
citizens, whether they are from the EU member states or the citizens of other states. The application of fundamental principles of EU law regarding freedom of movement of persons, goods and services leads to enacting new rules or amending the existing rules of the Hague Convention. In accordance with this, by enacting the Rome II Regulation, the conflict of law standards of international tort law in the EU area are unified, by the application of the rule of foreseeability and certainty in determining the applicable law for non-contractual liability for damage. Reaching a certain degree of foresee ability is the reason to accept the law of the place of the damage instead of the law of the place where the harmful event occurred, as a rule which will bring a certain measure of flexibility in the application of the conflict of law solution. The Rome II Regulation does not preclude the application of international treaties in which the EU member states are contracting states. The courts of the member states apply the conflict of law provisions of the treaties in force in their countries, and the courts of the member states which are not the parties to such treaties apply the provisions of the Rome II Regulation. This is the derogation from the desired European conflict of law harmonisation in favour of international rules, except for the treaties in which the contracting states are only the EU members.

\section{References}

Babić, Davor (2009).'Uredba Rim II-Uredba Evropskog Parlamenta i Saveta o merodavnom pravu za vanugovorne obaveze", Zbornik hrvatskog ureda za osiguranje o obradi i likvidaciji automobilskih šteta, Opatija, 2009, str.15-29.

Варади, Тибор; Бордаш. Бернадет; Кнежевић, Гашо; Павић, Владимир (2012).Међународно приватно право, Правни факултет Београд, Центар за издаваштво и информисање, 2012.

Dickinson, Andrew (2009).The Rome II Regulation: A Commentary, New York: Oxford University Press, 2009, deo 13.01 i dalje.

Dika,Mihajlo;Knežević,Gašo;Stojanović,Srđan (1991).Komentarzakonaomeđunarodnomprivatnomiprocesnompravu, Nomos, Beograd, 1991.

Dutoit, Bernard M.(1968), Mémorandum relatif aux actes ilicites en droit, u: Conference de la Faye dedroit international privé Actes et documents de la Onzieme session 7 au 26 Octobre 1968, Tome III, Accidents de la Circulation routi ere, Bureau Permanent de la Conference, p.20.

Gebauer, Martin (2000).Uniform law, General Principles and Autonomuos Interpretation, Uniform Law Review, no.4, 2000, bel.10, p.685. 
Живковић, Мирко; Станивуковић, Маја (2004).Међународно приватно правоопшти део, Београд, 2004.

Kadner Graziano, Thomas (2004).La responsabilité delictuelle en droit international privé eurpéen, Zeneva, München, 2004.

Kunda, Ivana (2007).Uredba Rim II-ujednačena pravila o pravu merodavnom za izvanugovorne obaveze u EU, Zbornik Pravnog fakulteta Rijeka, vol.28, br.2, 2007,str. 1269-1324.

Reese, Willis (1974). The Hague Convention on the Applicable to product Liability, InternationalLawyers, 8/74.

Sumampouw, Mathilde (1996). Les nouvelles Conventions de la Haye, leur application par les jugesnationaux, Tome II, Leyden, 1996, 263-269.

Tomljenović, Vesna (2012).Tumačenje kolizijskih pravila međunarodnih ugovoraprimer tumačewa kolizijskih odredaba Haške konvencije o prometnim nezgodama, Zbornik Pravnog fakulteta u Zagrebu, 62(1-2)2012, str.101-152.

Collins, Lowrence (1993).Dicey and Morris on the Conflict of Laws, London 1993. Хашка конвенција о закону који се примењује на друмске саобраћајне незгоде, "Службени листСФРј"- Међународни уговори 26/76.

Бечка конвенција о праву међународних уговора. "Службени лист СФРЈ" бр.30/1972.

Regulation (EC) No.864/2007 on the law applicable to non-contractual obligations (Rome II),Official Journal of the EU- OJ 2007 L 199/40.

Regulation (EC) No.593/2008 on the law applicable to contractual obligations (Rome I),Official Journal of the EU- OJ 2008 L77/6.

Нацрт Закона о међународном приватном праву Републике Србије, $w w w$. mpravde.rs , приступ 16.07. 2018.

Закон о решавању сукоба закона са прописима других земаља, "Сл.лист СФРЈ" бр.43/82, 72/82,"Сл.лист СРј” бр.46/96 и "Службени гласник РС” бр. 46/06.

Court Practice of the Court of Justice of the EU, Retrieved 11.07. 2018 from:curia. europa.eu/juris/document/document.jsf? text= applicable\%Blaw\%2Bto\%Btra ffic\%2Baccident\&docid

Домаћа судска пракса, преузето са:www.vk.sud.rs/sr-lat/baza-sudske-praksesuda,приступ 14.07.2018. 


\title{
Др Марија Крвавац,
}

Редовни професор,

Правни факултет Универзитета у Приштини, са привременим седиштем у Косовској Митровици

\section{ХАШКА КОНВЕНЦИЈА О МЕРОДАВНОМ ПРАВУ ЗА ДРУМСКЕ САОБРАТАЈНЕ НЕЗГОДЕ И УРЕДБА РИМ II}

\begin{abstract}
Резиме
Основни циљ Хашке конвенције био је олакшање накнаде штете посредством осигуравача аутоодговорности и побољшање положаја оштећених лица. Конвенција је резултат компромиса односно настојања аутора да помире различите приступе и тенденције у колизионом праву вануговорне одговорности. У складу са тим, решења полазе од примене права на које указују више тачака везивања истовремено пре опредељења за флексибилно везивање предмета спора. Примена одредаба конвенције има карактер унутрашњег извора те обухвата и меродавно право земаља које нисучланице ЕУ (без обзира на начело реципроцитета).

Уредба Рим II полази од традиционалног приступа тако што преузима решења која супостојала у међународном приватном праву држава чланица, а узима у обзир решења садржана у правима неких држава нечланица. У суштини, опште правило Уредбе потврђује примену права земље у којој се десио штетни догађај, али да би се избегла правна несигурност у случајевима када су последице штетне радње у различитим државама, ово правило је конкретизовано кроз примену права државе у којој је наступила непосредна штета. Жртве друмских саобраћајних несрећа имају могућност избора повољнијег права уколико су упознате са правом обе државе, чиме могу заштити своја права и обезбедити повољан правни третман. Иако повлашћени третман тужиоца није у складу са традиционалним европским правилима одређивања меродавног права, упућивање на основу отворене и флексибилне колизионе одредбе би требало да омогући правичност у сваком конкретном случају. Теорија заступа мишљење да се неуједначеност колизионих правила комунитарног права и Хашке конвенције у материји вануговорне одговорности за штету изазвану саобраћајном незгодом може превазићи изменама и допунама колизионих решења у изворима комунитарног права, доношењем новог акта секундарног законодавства или одступањем од обавезне примене конвенције у земљама уговорницама уколико и штетник и оштећени имају исто уобичајено боравиште.
\end{abstract}

Кључне речи: штета, саобраћајна незгода, меродавно право, право ЕУ. 